Dr Georgios Patsiaouras and Professor James Fitchett

School of Management

University of Leicester

Paper accepted for publication in the Journal of Historical

Research in Marketing

\title{
The evolution of conspicuous consumption
}

\begin{abstract}
Conspicuous consumption refers to the competitive and extravagant consumption practices and leisure activities that aim to indicate membership to a superior social class. Studies examining the symbolic role of luxury brands and status symbols, and the importance of interpersonal relations and upward social mobility via consumption choices, have been widely discussed in the marketing and consumer behaviour literature. There is, however, limited research on how the all-encompassing concept of 'conspicuous consumption' has evolved since the introduction of the term by Thorstein Veblen in The Theory of the Leisure Class (1899). Using a chronological periodization this paper seeks firstly to examine and discuss the impact of wider institutional and socio-economic forces on the evolution of conspicuous consumption phenomena. Secondly, and adopting a historical framework related to economic and marketing, we show how the concept of 'conspicuous consumption' has been reinvented with different terminology during the twentieth century by marketing and consumer behaviour theorists.
\end{abstract}




\section{Introduction}

The adoption of practices such as ostentatious display of goods and status consumption maintain a leading role in social relationships, with material or immaterial conspicuousness being conveyed via individual actions and behaviour. Conspicuous consumption, public display of goods or a desire for uniqueness and social membership via the possession of status symbols are diachronic and cross-cultural phenomena that define and characterize consumer behaviour (Solomon, 1992; Mason, 1998; Chaudhuri and Manjumar, 2006). Leaving aside the universality and timelessness of status-motivated consumption and focusing on Western developed societies, there seems little doubt that individuals' concern with self-image, fashion, and brand associations, strengthen and multiply the dynamics of consumer behaviour as a process which apart from satisfying basic needs also contributes to the establishment of social relations and the structure of social organization.

The importance of interpersonal relations in defining consumer preferences and choices was a concern for economists including Adam Smith (1776/1999) who suggested that, to some degree, consumption contributes to the maintenance or improvement of social standing. Thorstein Veblen (1899) is generally regarded as one of the first theorists to shed light on how the process of social comparison via the display of status symbols by members of the affluent and aristocratic leisure class operated. In his classic The Theory of the Leisure Class Veblen questioned the conventional neoclassical economic views of the time and produced one of the early theories of status-driven consumption. Veblen argues that consumer demand for services and goods derives from a need to establish social networks and a desire to emulate higher social classes and economic groups. He named this kind of universal and diachronic consumer behaviour 'conspicuous consumption', an endless procedure that played a significant role in social mobility and economic development of the United States at the end of the 19th and beginning of the 20th century. Although the importance of status-seeking consumption practices had been long recognised as one of the most fundamental forms of consumption, a fuller examination of the phenomenon in marketing and consumer behaviour literature becomes noticeable by its absence (Mason, 1998). Here we argue that the lack of historical introspection regarding the intellectual antecedents of the discipline along with superficial examination of early accounts about the generation of consumer desires, has resulted in the marginalization of ideas that form the grounds of the conceptual basis of contemporary marketing theory and consumer research. 
By reviewing the work of the theorist who originated the term 'conspicuous consumption', this paper seeks to examine and critically discuss the evolution of status-seeking consumption phenomena throughout the $20^{\text {th }}$ century and to highlight how institutional, social and political factors have contributed in the reinvention of the concept with different terminology.

\section{Conspicuous consumption before Veblen}

Before presenting a summary of Veblen's theory of the symbolic meaning of status symbols, we begin with a very brief examination of discussions about ostentatious economic phenomena that occurred prior to Veblen's era. Flamboyant display has been evident since the time of the Roman Empire. Cicero described Mark Antony as an emperor accompanied by wild animals, actresses and custom chariots which sought to exhibit his social status and rise in power. Anthropological studies (Yamey, 1964) on capital, saving and conspicuous consumption practices of primitive societies suggests that display of wealth was deemed a wasteful action and the individual who was aiming to promote his material superiority was condemned and often exorcised from the community. From a cross-cultural perspective, it can be observed that the importance of conspicuous economic display to social stratification of the community or group was defined to a great extent by environmental/political conditions and cultural norms. For example, in the traditional social caste system of India, prestige and social status were attributed primarily in terms of hereditary group membership and occupational categorization, with status consumption playing a minor role in the arena of social competition (Lannoy, 1971; Chaudhuri and Manjumar, 2006). Studies by Mauss (1923) and others examining 'gift exchange' (see Gregory 1982) also emphasise the conspicuous and visible use of material culture and goods to make stable categories of culture. Obvious parallels can be also drawn, albeit in contrast, to the complex exchange and destruction/waste rituals described by Malinowski (1922).

As Weber (1930) suggested, in Western Europe of the $16^{\text {th }}$ and $17^{\text {th }}$ century the economic principles of Mercantilists and Calvinist religious beliefs supported a view that saving and investment should characterize the economic actions of individuals. Ostentatious display of goods and status symbols was stigmatized as a time-consuming activity that did not support development and well-being (Mason, 1998). The economic and social scenery rapidly changed with the advent of the Industrial Revolution that established a novel and dynamic commercial reality where rising fashions, interpersonal relations and product 
symbolism stimulated individuals to immerse themselves in a more diverse range of consumption practices. Rising incomes, geographical mobility and technological development brought new employment opportunities and the emergence of an ambitious middle class, whose members were willing to take part in conspicuous consumption activities and ostentatious behaviour. Previously these activities and the significance attributed to them had remained principally the preserve of aristocratic elites (Page, 1992). Although Marx $(1883 / 1981)$ was not interested in producing a theory of consumer behaviour, he explicated how relations of production define class consumption and people's needs according to their hierarchical role in the production system of early capitalism. Back in the middle of the $19^{\text {th }}$ century, Rae (1834/1964) offered one of earliest theories of consumer demand stating that consumption is an active process of socialization and goods function as markers of social class (Edgell and Tilman, 1991; Alcott, 2004). As economic surplus was steadily being concentrated in the hands of relatively few individuals and families in the United States of America of the $19^{\text {th }}$ century status claims and a hierarchical organization of society began to arise (Twain, 1968). The affluence and exhibition of wealth during this period prompted Veblen to conduct research into the consumption practices of the upper and middle classes during the golden age of American conspicuous consumption $(1860$ - 1914), where the financial rise of the industrial elites exhorted conspicuous economic excess and a status revolution.

\section{The Theory of the Leisure Class (TLC)}

Five years before the publication of the TLC, the first edition of Alfred Marshall's (1895) Principles of Economics was published in England. The book became the cornerstone of the neoclassical economic view for many decades. Marshall superficially acknowledged a social as well as a psychological dimension to consumption and the need for recognition and attribution of status as a major feature of determining the purchase of goods such as clothing. In the main thrust of his book can be found the representation and description of a rational and mechanistic 'economic man' (consumer) whose status considerations play a secondary and negligible role. Veblen's perception of economic reality, and market reality in particular, was quite different and probably more sophisticated. As Assistant Professor in Economics at the University of Chicago, he developed a continuous interest in the developing nature of status consumption phenomena, socio-economic change and cultural norms. By including and synthesizing these ideas into the Theory of the Leisure Class Veblen produced an incomplete 
evolutionary account of the individual's status-seeking desires from primitive to modern industrial societies (Patsiaouras and Fitchett, 2009).

One of Veblen's major concerns was to examine how technological development and the rise of economic surplus exhorted the nonviolent members of archaic societies to evolve into the warlike people who dominated barbaric life. The dynamics of antagonism and rivalry were created within groups, through securing the basic means for survival and through the inheritance and learning of new habits related to ownership and display of commodities. War and hunting pervaded social life and members of the community also experienced the emergence of the institution of private property, a feature absent from the life of archaic communities. Together with the establishment and development of individual ownership grew the incentive of emulation, since the diversification of employments and the exploitative activities of men motivated escalating comparison. Epithets such as 'honorable', 'respectable' and 'meritorious' were attributed to warriors and hunters who exhibited the 'qualities' of superior force, violence and aggression. The skilful use of arms was considered a sign of honour, along with the possession and display of large numbers of women, slaves, horses and booties in the form of status symbols.

With the arrival of the second sub-stage of barbarism, what Veblen described as 'later barbarism', the recognition and attribution of status according to the aggressive behaviour of the members of the community was replaced by the acquisition of goods. The 'struggle for subsistence' was substituted by the 'struggle for wealth' and progressively, private wealth substituted the good repute assigned to bellicose and competitive activities. The acquisition of property and wealth conferred honour on the individual and replaced the display of heroic and violent achievements.

Focusing his interest on a post-agrarian environment, which partially reflects an economic and social context as outcome of the Industrial Revolution, Veblen argued that the production of surplus contributed to the emergence of the institution of private property and the distinction between industrial and economic employments. Consequently, individuals undertake to satisfy their needs for self-respect, high esteem and social standing not only through the reputability of professions and work but also via the acquisition, accumulation and display of goods. Furthermore, an excess of wealth is more highly valued than a certain standard of prosperity. Pre-empting the discussion of cultural capital by Pierre Bourdieu (1984), as the accumulated stock of knowledge related to intellectual traditions and products 
of artistic value, Veblen pointed out how aesthetic taste relates to status position. The learning and display of gentle and sophisticated manners indicated unproductive consumption of time and could be exercised as a mark of social distinction. As the first economist who paid attention to this tendency to consume for status Veblen generalized and simplified the analysis of socially-complex consumption phenomena (Bronner, 1989) and limited his descriptions primarily to ostentatious and visible consumption actions (Campbell, 1987). Even today Veblen's name has been inextricably associated with the term 'conspicuous consumption'; a kind of exceptional consumer behaviour. Observing the reception and discussion of Veblen's incomplete but imaginative ideas on conspicuous consumption by economists of consumer demand and early theories of consumer behaviour sheds some light on how the concept has been used and evolved until the Second World War.

\section{Institutional economics, recession and the early reception of the theory of conspicuous consumption (1899 - 1945)}

Following Mason (1981), the escalation of conspicuous consumption, recorded in the period 1890-1910, was followed by public reaction against the phenomenon of the 'idle rich' and high spending at the beginning of the $20^{\text {th }}$ century. As Hunt (1996) observes, the rise of manufacturing capitalism introduced competitive struggles between social and class interests that eventually led to anti-luxury and sumptuary regulations. Progressive political programmes sought to encourage and stimulate more and better education and simultaneously to diminish competitive economic display. As expected, the surplus of wealth and desire to compete for social status was reduced after the outbreak of the First World War. Consequently, a major shift occurred in public attitudes towards ostentation, excess and the conspicuous celebrations of the 'Gilded Age' (Galbraith, 1987).

Although the TLC had a considerable impact on the intellectual circles of economists and sociologists at the time of its publication, Veblen was disappointed by the reception of the book as a sociological treatise on the mannerisms of the aristocratic classes (Dorfman, 1934). Veblen's view that a significant part of consumer behaviour is driven by competition and status-seeking considerations prompted neoclassical economists interested in consumption to marginalize his observations (Dobriansky, 1957). This changed after the Great Depression (1929 - 1933) and its disastrous impact on the industrial wealth of America and the conspicuous expenditure patterns of the rich. Before and immediately after the publication of the TLC, the economist John Cummings (1868 - 1936) had been the most 
persistent and conservative critic of Veblen's views about the consumption of socially acceptable goods (Tilman, 1992). In a polemic review of the TLC, Cummings (1899: 432) pointed out that "in Dr Veblen's philosophy....all our judgements are based on invidiousness" and "the more universal and dominant the spirit of emulation is, the more essentially generic it is in its character." In 1931, two years after the death of Thorstein Veblen and the outbreak of the Great Depression, Cummings wrote about the TLC:

\footnotetext{
"It was hard for me to accept him or his philosophy. It went against my grain. I was eager to find it lop-sided and unreal....My review gives good evidence that I didn't at the time fairly appreciate the contribution Veblen was making to our economic and social philosophy. I have often wondered how I could have been so blind. In the years since, we have all seen the accumulating evidence of the widespread influence of Veblen's analysis of social and economic behaviour, as set forth in his Theory of the Leisure Class..." (Dorfman, 1934: 507)
}

Notwithstanding the TLC and Veblen's work on conspicuousness and social display receiving wider attention after the recession, economists remained sceptical about the infusion of social considerations within prevailing assumptions about the behaviour of consumers. Apart from Wesley Mitchell, one of the founding fathers of institutional economics, who claimed that a deep and penetrating understanding of market behaviour is rendered impossible without a social analysis of economic behaviour and consumption, some of the most prominent economic theorists (Wieser, 1914; Carver, 1918; Knight, 1925; Viner, 1925) hesitated or resisted acknowledging the importance of socially-inspired consumption and the interpersonal effects on consumer demand (Tilman, 1992). During the 1920s and 1940s, Veblen's name and reputation was affiliated with members of the institutional economic movement, who were proposing a historical understanding of human institutions, more focus and attention on problems of social (inter)action and critical examination of business and financial institutions (Hodgson, 1988; Hodgson, 2006). Their arguments attracted the interest of some early theorists of consumer demand who paid attention to the notion of conspicuous consumption.

Jones and Monieson (1990) convincingly argue that between 1890 and 1910 a growing body of American economists working on the field of consumer behaviour had been exposed to economic views which contrasted with the principles of neoclassical theory. Most 
of these economists had been German-trained and followed the scientific principles of the Historical School of Economics, a social scientific approach interested in: a) a pragmatic approach to economic phenomena, b) statistical analysis and observation of human behaviour and c) focus on a historical understanding of socio-economic events (Jones and Monieson, 1990). This type of approach towards economics was more able to accommodate the Veblenian observations of conspicuous consumption compared to the rational views and calculus principles of neoclassical economics. Despite the fact that the German Historical School failed to offer a compelling substitute to neoclassical views or to propose a detailed theory of consumer action, its existence gave fresh impetus to the amalgamation of institutional economic thinking and early marketing theories (Jones and Monienson, 1990; Mason, 1995). Partially influenced by the work of Veblen, and especially his observations in the TLC, institutional economists embraced the idea that 'group behaviour' should be an essential theme of economic study since human economic behaviour is in a state of constant flux and individuals' motives are mostly instinctive (Webb and Shawver, 1989; Schmid, 2004). Contrary to classical economic theory, the institutional approach emphasized consumption instead of production, favoured 'societism' instead of individualism and defended the existence and distribution of public wealth contrary to private riches held by entrepreneurs (Dorfman, 1963; Ebner, 2008). As Bartels (1951:3) argues, progressive economic ideas had been the main stimulus of early marketing thought and institutional economists like John Rogers Commons (1862 - 1945) had a significant role to play in the development of these ideas. As Professor of Economics at the University of Wisconsin, the original centre for the development of marketing thought (Bartels, 1962:34), Commons taught and tutored some early thinkers of marketing like Paul D. Converse. In his groundbreaking publication Institutional Economics - Its Place in Political Economy, Commons (1934) suggested that any phenomenon observed in the marketplace which possesses a 'dynamic' instead of 'static' nature should come under the close scrutiny of institutional economics and defined an institution as "collective action in control of individual action" (Commons, 1934: 69). Commons and his former teacher Ely popularized a historical approach to economic science with emphasis to be laid on the general welfare of society and its contribution to answering economic (and marketing) problems (Jones and Monienson, 1990).

As Webb and Shawver (1989) suggest, some indirect links can be traced between early marketing theorists, such as Converse and Beckman - who approached the concepts of 
dynamism within the marketplace, business cycles, patterns of consumer spending and the causality behind the development of marketing phenomena - with the institutional ideas of Commons and Veblen. Nevertheless, the neoclassical interpretations of consumption phenomena prevailed over the development of economic and marketing thinking until the outbreak of the WWII (Goodwin, Ackerman and Kiron, 1996) and the inability of institutionalists to offer a methodical treatise of their theory together with an explanation (or remedy) for the Great Depression led to the decline of their intellectual movement (Hodgson, 1988). Subsequently, Veblen's ideas regarding the social and interpersonal effects on consumption preferences and practices remained vague and under-researched by the economic theories of consumer demand.

\section{Motivational research and conspicuous consumption}

The most dominant early school of marketing thought - the Functional School (Bartels, 1965) - did not pay particular attention to the notions of ostentatious economic display and status symbolism. A small number of economists after 1925 began an exchange of ideas with other disciplines (primarily psychology and sociology) so as to elevate the understanding of the complex consumer theory and many professionals interested in market research followed (Mason, 1995, 1998; Friedman, 2004). As result, trained psychologists and psychoanalysts experimented via the application of psychological principles on consumers' impulses, preferences and motivations with very profound effects on the development of advertising. In the 1930s Paul Lazarsfeld initiated the field of qualitative motivation studies aiming to understand some of the basic drives and motivations underpinning consumer behaviour (Tadajewski 2006). The inability of consumer demand theory to explain the psychological factors and social incentives of buyer behaviour led to the emergence of psychoanalytic methods, interviews, and participant observation for the prediction of consumption choices in particular and prearranged circumstances. Although the interest in consumption phenomena and marketing research was continuously developing, the embryonic discipline of marketing was still recognized as a derivative of (agricultural) economic thought and as a useful tool to interpret the complexity of consumption theory (Mason, 1995).

It is only after 1935 that the intellectual gap between economists and marketing theorists became noticeable. John Maynard Keynes (1936) seminal publication The General Theory of Employment, Interest and Money affected the way economists viewed and interpreted consumer demand theory. Keynes attacked the idea that the end of consumer 
behaviour is utility and profit maximization, a view held by the majority of neoclassical economists. Without elaborating on the formation of consumption preferences and desires, he argued that luxury consumption and ostentatious economic display had a positive impact on demand, employment and money circulation. By acknowledging, in economic terms, the importance of the propensity to consume for status, Keynes seemed to hold a sympathetic view of Veblen's ideas (Vinning, 1939; Mouhammed, 1999). However, the impact of Keynes' theory on the economics of consumer demand, and possibly early marketing theory, is far more complicated and lies outside the scope of this review. Leaving aside the impact of the Great Depression on consumer behaviour, the following section aims to examine followers and critics of conspicuous consumption theory in the post-war period (1945-1975) of mass consumption, technological development and affluence in Western economies.

\section{Post-war period and mass consumption (1945 - 1975)}

A long period of economic depression beginning in the 1930's was followed by the economic realities and consequences of the Second World War. Consumption of goods and services was reduced to the minimum given that public policies, and subsequently advertising campaigns, aimed to meet the needs of a war economy (Blum, 1976; Covert, 2003). Wartime restrictions on spending and rationing on personal consumer preferences decreased and especially in England - substantially reduced demand for luxurious products (Deaton and Muellbauer, 1980). Across Europe in the aftermath of the Second World War goods which had previously become accessible to a mass consumer public, including everyday commodities such as butter and eggs, and consumer electronics and technologies, took on luxury signification. Landsman (2005) discusses some of the political and economic consequences of these conditions in his analysis of post war Berlin, and the competition between Eastern and Western interests to compete in terms of the public availability of minor 'luxuries'.

It is not until the middle of the twentieth century $(1947$ - 1950) that consumption preferences began to boost the escalating rise of (post-industrial) capitalism in Western developed societies (Bocock, 1993). Television advertisements produced increasing visibility of product images associated with social prestige and radically altered the communication of conspicuous consumption preferences (Galbraith, 1987). Social groups from middle-income 
socio-cultural backgrounds, embarked on the competitive game of conspicuous consumption; which seemed to become broader, far more sophisticated and complex, compared to the extroverted and ostentatious display of goods during the 'Gilded Age.' Industrial prosperity, technological advances and mass demand for products characterized the socio-economic scene of America, and high levels of job mobility in the rising service sector, together with increased educational opportunities created a new middle class of white-collar workers (Riesman, 1953; Collins, 2000). This rapid economic development induced a significant increase in consumption and socio-economic phenomena such as ownership of status conferring goods, socially-motivated consumer demand, and display of wealth.

Questions regarding the role and implications of consumption became more relevant to the agenda of sociologists, marketing theorists and economists during the $1950 \mathrm{~s}$ and turbulent 1960s (Mason, 1981). Ernest Dichter (1907 - 1992) is acknowledged as one of the founding fathers of motivational research, building on Freudian psychoanalysis to reveal consumers' subconscious desires and feelings about commodities and services (Savitt, 1980; Stern, 2004, Tadajewski, 2006). Establishing the Institute for Motivational Research in 1946 Dichter became a pioneer of advertising research, who not only adapted psychoanalytic methods to study marketplace behaviour but also contributed to the introduction of the field of qualitative consumer research (Packard, 1959). Flirting with cultural anthropology, Dichter (cited in Tadajewski, 2006: 436) seems to be very close to Veblen's ideas by arguing that "the day-to-day behaviour of twentieth century man - even if he lives in Brooklyn, on the outskirts of Paris, or in South Italy - is as worthy of study as the Samoans or the Trobrianders." During the same period and drawing upon early theories of consumption, McMurry (1944) summarized the main psychological findings on buyer behaviour to show how feelings of inferiority - stemming from economic comparisons and social status considerations - have the potential to turn into decisive factors in the mimesis of purchasing decisions.

This is the beginning of an interest among consumer behavior theorists to focus more explicitly on issues of product symbolism, ostentation and consumption for social status. A renewed impetus came from advertising research and some pioneers of marketing research showing interest in the psychological underpinnings between status seeking economic phenomena and symbols of status (Leavitt, 1954; Katz and Lazarsfeld, 1955). Trained in psychology and economics, Katona $(1951,1953)$ observed that the wealth and 
material comfort of the post-war years encouraged individuals to actively seek status and prestige through the display of commodities and leading status symbols. One year later, Veblen's name appeared on the title of an economic study - fifty-one years after the TLC when Leibenstein (1950) published his well-known article "Bandwagon, Snob and Veblen effects in the Theory of Consumer Demand". Leibenstein intended to remind mainstream economic theorists of Veblen's contribution to their discipline and coined the term 'Veblen effect':

"By the Veblen effect we refer to the phenomenon of conspicuous consumption; to the extent to which the demand for a consumer's good is increased because it bears a higher rather than a lower price." (Leibenstein, 1950: 189).

According to Leibenstein, consumers' desire to emulate particular lifestyles or to look exclusive had remained out of the sphere of inquiry of theories of consumer demand and the analysis of the interpersonal effects of consumption should be divided according to functional and non-functional demand. He also mentioned that one of the non-functional forms of demand was 'irrational demand' and without detailing the nature or the psychological needs of the consumer himself, a central trait of Veblen's analysis, Leibenstein moved his discussion to the concepts of bandwagon and snob effects. He defined the term bandwagon effect as the economic phenomenon which causes increasing demand for a commodity due to the fact that economically superior individuals consume the same product. The bandwagon effect helps consumers to 'get into the swing of things', to associate their image with superior lifestyles, or to be fashionable. In other words - to keep up with the Joneses. On the other hand, the snob effect refers to an individual's desire to differentiate himself from the 'common people', thus the purchase, exhibition and consumption of popular and widely accessible commodities is rejected. Overall, Leibenstein's short paper offered some novel insights regarding the importance of external factors on consumer demand theory and suggested that the price of commodities are shaped according to consumer's sociopsychological needs. By reducing Veblen's complex arguments to a one-sided theorem of determining specific prices, Leibenstein encouraged students interested in economics to marginalize the anthropological insights of the TLC regarding the evolution of emulatory motives, desires and consumers' continuous dissatisfaction, to mention but a few. A year before Leibenstein's publication another economist, Duesenberry (1949) recognized and underlined the importance of social factors for the formation of consumption preferences. He 
argued that luxurious commodities and high standards of living have emerged as means of social differentiation and superior status.

\section{Interdisciplinary approaches to conspicuous consumption}

Generations of orthodox economics either marginalized or superficially examined Veblen's observations but as mentioned above, the phenomenon of mass consumption, frenzied advertising activities and psychological findings on the motives of consumers captivated the interest of academics in other disciplines. The conventional sociological mainstream also had a limited appreciation for the ideas of the TLC (Mestrovic, 2003). Veblen's socio-cultural accounts of excess competition and status consumption were largely irrelevant to Parson's theories on the structures of social action; ideas which have been very popular and influential for the sociological agenda of their time (Tilman, 2007). An exception can be found in the work of David Riesman (1961) who observed and responded to the rise of the service-based and consumption-driven new economy. He presented a model of different American social characters and identified and explored the main features of three cultural archetypes: the tradition-directed, inner-directed and other-directed individual. Riesman claimed that other-directed individuals, a category wherein most Americans belonged, were in a constant search to behave according to norms established by peers and their consumer behavior was primarily driven by their concern to conform to the societal standards or to properly fit in social groups. We observe that Riesman's other-directed character builds upon Veblen's conspicuous consumer since they share many psychological and cultural traits, such as the same increased sensitivity to fashion, mimetic behaviour and conspicuous display of wealth.

Veblen's writings, together with his reviews on Marxist thought, created a centre of attention for the scholars of the Frankfurt School. Their analysis and criticism of Veblen's ideas vary and include scepticism of Veblen's technocratic views regarding the development of the American economy, technological determinism, false interpretation of America's class conflict and finally Veblen's misunderstanding of consumer culture and aesthetics, as a theorist who conceived anything beautiful as wasteful and insufficient (Adorno, 1941; Stabile, 1982). Building on the Marxist idea of 'commodity fetishism', Adorno aimed to explain how the ceremonial/conspicuous consumption practices connect with the transcendence and emancipation from industrialized work life. Although there is limited analysis on Veblen's anthropological and socio-historical framework of consumption 
practices, Adorno criticized Veblen's almost melancholic and nostalgic admiration for the primitive stage of human organization and incapability to propose future plans for social change and development. However, in the following years, Marcuse's (1968) thorough critique of the one-dimensional modern man in capitalist societies concurred with Veblen's satirical comments on the American conspicuous consumer, who is continuously manipulated by fashions and participates in a national system of status and prestige (Simich and Tilman, 1980). Fromm (1947) dived into the abyss of human nature and critically analyzed the incentives behind the everyday actions of 'the marketing man'. Similar to the eccentricities of the conspicuous consumer, the marketing man is obsessed with social status and his insatiable desire for prestige translates everything into objects of transaction and consumption. Theorizing about the amalgamation of humanistic drives with cultural needs, Fromm suggested a more authentic and autonomous stance for the consumer who is socially-driven by a having mode orientation instead of a being orientation, as a path leading to selfactualization (Shankar and Fitchett, 2002). Veblen and Fromm would probably concur on individuals' inexorable appetite for the ownership and accumulation of goods, a state that enhances the idea of having instead of becoming an active entity.

From a marketing perspective, Pierre Martineau (1958), the Research Director of the Chicago Tribune and an influential promoter of motivational research, infused social scientific approaches into marketing practice and based on the social mobility/stratifications theories of Warner et al. (1949) explored how a variety of consumption practices aim to improve consumer's social class position. Extending and building upon the notion of conspicuous consumption, Martineau's study (1958:130) crystallized the evidence of a social class system that activates and instigates the pressure for social differentiation and suggested that the middle class consumer is a 'mobile and risk taker individual' willing to spend money 'for various symbols of upward mobility, display and consumption.' Following an upward trend in the sociology of consumption and Martineau's insights into social stratification and consumer behaviour sociologists began to re-examine the extent to which social class becomes an important determinant of consumer behaviour (Kahl, 1957; McCann, 1957; Newman, 1957; Coleman, 1961; Nam, 1963). Likewise, Bayton (1958) highlighted the role of products as a means of enhancing personality traits, a technique used by marketing and advertising strategies. Acting as a forerunner of high and low involvement product theories, 
he argued that some consumer goods entail a higher degree of ego-involvement for the decision-making activity whilst others have relatively low ego involvement.

\section{The Status Seekers in the Affluent society}

The work of Vance Packard and Kenneth Galbraith offered some of the most popular discussions on consumption in the post-war period and attacked the standardized economic assumptions of consumer demand by highlighting the nature of conspicuous economic display during the period of mass consumerism. Initially trained as a journalist and writer and an 'insider' in the business and commercial side of the television industry, Packard observed how the rising advertising medium entered almost every American household but was simultaneously turning into the most powerful mechanism behind the motives of statusseeking consumers. With his bestselling book The Hidden Persuaders, Packard (1957) demystified the then dark 'unknown' art of advertising to the general public. In a chapter of the book entitled 'Selling Symbols to Upward Strivers', Packard (1957: 106) quoted Lloyd Warner as follows:

\footnotetext{
"Within the status systems something else operates that is at the very centre of American life and is the most motivating force in the lives of many of us - namely what we call social mobility, the aspiration drive, the achievement drive, the movement of an individual and his family from one level to another, the translation of economic goods into socially approved symbols, so that people achieve higher status."
}

The success of the Hidden Persuaders was followed by The Status Seekers (Packard, 1959), a Veblen-like study of social norms and wasteful consumption habits. It was a period in which a growing body of intellectuals, academics and marketing researchers held and supported the view that increased consumption, job mobility and a new middle-income class had become the mechanisms of building a truly 'open' and egalitarian political system. The uniqueness and affluence of the new social system were praised and eulogized by economists and political theories during the Cold War period (Horowitz, 1994). In opposition to those accounts, Packard argued that the escalating need for status striving strengthened social class distinctions, destabilized personal prosperity/happiness and served the interest of very few entrepreneurs. Packard's observations attacked the well-promoted idea of an affluent and classless society and the book explicated how advertising techniques increased class barriers. 
In the same period and following Veblen, Galbraith argued that the phenomenon of status emulation lies at the very heart of power politics in modern American society. At the end of the 1950s, Galbraith's (1956/1987) best-selling book The Affluent Society revived and applied Veblen's and Mitchell's institutional economics to a popular audience (Hood, 2005). Galbraith remarked that escalation in production and advertising strategies intensify, propagate and proliferate consumers' wants. However, these wants do not always stem from intrinsic and basic needs but from an individual's desire to increase his social standing and satisfy hedonistic wants. Advertising campaigns produce and promote "craving for more elegant automobiles, more exotic food, more erotic clothing, more elaborate entertainment indeed for the entire modern range of sensuous, edifying and lethal desires" (Galbraith, 1957/1987: 115). We can note here that Galbraith's conspicuous consumers are less socially directed compared to those depicted by Veblen, attributing the generation of conspicuous consumption practices primarily to productive forces, advertising and manufacture revolution. The continental social theory of Pierre Bourdieu and Jean Baudrillard, which discusses the meaning of objects and the impact of consumption practices on cultural reproduction, social stratification and individual's perception of identity and social standing, represents a further step in the evolution and application of Veblen. Bourdieu (1984) conducted an extensive large scale data collection, based on the existing social classes of France in the 1960s, and examined and pointed out how taste, cultural and economic capital have been used by members of specific social classes to differentiate themselves from the rest. Describing cultural capital as an accumulated stock of knowledge, Bourdieu focused on the process of how artistic and intellectual establishments reproduce inequality amongst social groups.

Challenging and updating previous ideas on conspicuous consumption, which related mainly to products and services, Bourdieu claimed that the aesthetic aspects of preferences turn into the most eminent vehicles both for social upbringing and marginalization. Reversing Veblen's 'trickle down' model, Bourdieu concluded that the upper classes borrow consumption habits and popular tastes from the working classes so as to confuse the pretentiousness of the middle class and retain their dominant position. The contribution of Bourdieu on consumption studies is comparable that of Veblen (Bocock, 1993). As Trigg (2001) argues, we can see Bourdieu's contribution as a complement to Veblen's theory and even recognize a potential development of the theory of conspicuous consumption. Baurdillard was also influenced by Veblen's thesis and refers to it directly in his early work 
on consumer society (1968 - 1981). In The System of Objects, Baudrillard (1968/1996) follows Veblen by explaining how 'mental structures' and 'cultural systems' have arranged a symbiotic but not always synergistic relationship where objects and their signified meanings operate in the definition and attribution of status for consumers.

\section{Towards consumerism and increased conspicuous consumption (1975-2000)}

The era of widespread conspicuous consumption practices, beginning in America during the middle of the 1950s continued throughout the 1960s and 1970s and business organizations produced a wide range of status based products and strategies so as to meet a growing consumer demand for social status, distinction and differentiation (Mason, 1998). In the same period marketers and advertising agencies adapted their strategies and campaigns by developing and promoting products which both satisfied consumers' intellectual taste and positioned them closer to aspirant social groups (Page, 1992). Additionally, we notice a transformation from the socially conservative and highly materialistic 1950s to the growing counterculture and political activism of the 1960s that caused the emergence of new reference groups and a rearrangement of social stratification. The introduction of neo-liberal theories (Friedman, 1957) regarding the macro-economic function of 'open markets' popularized the notion of consumer sovereignty as a factor of social competition amongst individuals for higher social standing and status differentiation (Slater, 1997). Furthermore, status-motivated consumption ceased to be viewed as a primarily American phenomenon. Following the postwar period rising ostentatious economic display could be observed in many European countries, mostly in Britain (Bocock, 1993). This trend has continued into the end of the $20^{\text {th }}$ and early $21^{\text {st }}$ century with attention to turning to conspicuous consumption in China, India and other 'emerging' economies.

Academic efforts to amalgamate the principles of social psychology with economic behaviour revitalized the attention and interest in status consumption and product symbolism (Mason, 1998). Moreover, the legacy of motivation research theory and an upward trend in the experimental analysis of human 'behaviour' (Wann, 1964; Watson, 1970) advanced the emergence of general and all-encompassing models of consumer behaviour. The introduction and popularization of the philosophy of behaviorism in the field of economic theory, marketing and consumer behaviour during the mid 1960s and beyond led to rationalistic interpretations of status-consumption phenomena according to the standardized methodological principles of positivism. Sociological approaches on conspicuous 
consumption during the mid-1950s were replaced by the work of marketing theorists and psychologists who followed the movement of behaviorism and its application as a novel scientific economic approach towards consumption that favored the mechanistic theorization of the modern individual (Foxall, 1999). Terms such as 'stimuli', 'responses', 'rewards' and 'learning' gained prominence and permeated the vocabulary of consumer demand theorists. Such enthusiasm for popular psychological theories resulted in the introduction and emphasis on concepts such as risk taking, mental and information processes, and outputs relating to cognitive studies of behaviour.

The first detailed description of a consumer decision model came from Nicosia (1966) and a series of textbooks (Engel et al., 1968; Howard and Sheth, 1969) with the ambition to offer a holistic explanation of the process of consumer behaviour following soon after. These models suggested that the process of buying commodities can be identified, classified and explored by four different levels of consumption activity; specifically a) consumer attitude formation, b) information search and evaluation, c) purchase and d) postconsumption feedback. Even today, a plethora of contemporary academic textbooks and papers in the field of consumer behaviour recycle, promote and re-think these popular terms, introduced in the mid-1960s. Levy (1959) was possibly the first consumer behaviour theorist who placed special emphasis on the symbolic meaning of brands as indicators of consumers' social status. Building on Martineau's insights into social stratification and consumer behaviour, Levy suggested that the interrelationships and interactions amongst members of different social classes represent seminal factors for the (re)production and learning of consumer behaviour:

\footnotetext{
"Symbols of social participation are amongst the most important factors in marketing. Like it or not, there are social class groupings formed by the way people live, the attitudes they have, and the acceptance and exclusiveness of their association. Most goods say something about the social world of people who consume them. The things they buy are chosen partly to attest to their social position." (Levy, 1959: 122)
}

Levy's groundbreaking publication proposed an alternative to the functionalist perspective of consumer behaviour science, by viewing the symbolic aspects of products as possessors of social meaning. Quite explicitly, Kotler (1965) had been the first marketing 
theorist who proposed a Veblenian Psychological model of consumer behaviour - along with the Pavlonian and the Freudinian Psychoanalytic models - as a theoretical approach existing outside the marginal utility theory of demand. With the publication 'Broadening the Concept of Marketing', Kotler and Levy (1969) suggested the disentanglement of marketing ideas from a traditional business context and the application of the marketing concept to non-profit organizations, services, persons and ideas. The same year, and following a conference on consumer behaviour theory, the Association of Consumer Research was formed and five years later the same organization published the Journal of Consumer Research (JCR). The increasing interest in the area gradually induced a schism from the discipline of marketing (Holbrook, 1987; Holbrook and O'Shaughnessy, 1988) and by the end of the 1980s the fields of (primarily) psychology, economics, sociology and anthropology provided the most popular sources of study for consumer researchers (Leong, 1989).

In the 1990s, consumer research moved far beyond the simplistic concepts of buying and consuming and the influx of social scientific approaches has produced a complex mosaic that includes the study of: judgments, deviant and compulsive behaviour, illicit consumption, consumer learning, attention, involvement, innovation, cross-culture consumption, ethnic and geographical differences to name but a few. Consumer researchers retained an interest in long-established and diachronic concepts such as motivation, status groups, consumer perception and retention, emotion, hierarchical needs, vicarious consumption, mimetic consumption, semiotics and status symbolism, hedonism, self-esteem and inferiority, status symbols, group dynamics and socialization processes. Directly or indirectly, these concepts relate to the interpretations behind the motives of conspicuous consumers.

\section{Post-affluent societies and status consumption}

The archetype of the conspicuous consumer and the individualistic desire to differentiate via consumption did not disappear during the 1970s. On the contrary, new educational and entrepreneurial status and reference groups reinforced middle class consumers' need to belong within a peer group or to a team of professionals who expressed their taste and occupational identity through distinguishable consumption lifestyles (Mason, 1981). At this stage the term professionalism was increasingly used to indicate social status and association with the new power 'elites.' The recognition of a more market-oriented 
society subsequently increased the significance of status-driven consumption and created a centre of attention for behavioural and social scientists. Urbanization, fluid social relationships, product diversification and the breaking down of traditional concepts such as education, social class and occupation, stimulated the dynamics of competitiveness and emulation. The representation of such a universe of commodities and desires offered a chaotic picture of the marketplace. In the mid 1970s marketing segmentation strategies aimed to identify homogenous groups of consumers (Smith, 1956; Green, 1977; Wind, 1978), and consequently similar groups of status-seeking consumers. The increasing availability of mass credit facilities and discounts shaped consumer society and liberated individuals' desire to acquire additional status symbols with the promise of continuous future credit support (Ritzer, 2001).

\footnotetext{
"In fact, increasingly important symbols in our society are the number of credit cards one has in one's wallet and the collective credit limit available on those cards. The modern status symbol is thus debt rather than savings. In sum, credit cards emphasize a whole series of things that can be quantified - number of cards, credit limits, amount of debt, number of goods and services that can be purchased, and so on." (Ritzer, 2001:83).
}

Innovative segmentation techniques and highly organized applications of quantitative marketing research questioned the utility of traditional sociological constructs such as social class. A debate about the validity and legitimacy of social class or income for the prediction of consumer behavior occurred in the mid-1970s and lasted until the 1980s (Curtis, 1972; Myers and Mount, 1973; Schaninger, 1981; Dominquez and Page, 1981). This resulted in the diminished importance of social class for marketing theorists (Coleman, 1983) and, by association, theories of conspicuous consumption. However, ostentatious economic display and conspicuous consumption intensified during the 'materialistic' decade of the 1980s. Interdisciplinary approaches were applied to the study of consumer behaviour, a fact that gave a fresh impetus to rethink an exceptional behaviour like conspicuous consumption. As Page (1992) argues, the aspirant middle-class managerial elites of the 1970s evolved into the status-seeking yuppies of the 1980s, representing individuals who enjoyed conspicuously consuming a variety of luxury goods so as to position and establish themselves within an elite professional class. Belk (1986) details how the notion of conspicuous consumption was back 
for the masses and the yuppies' self-centeredness found relief in ostentatious economic display, hedonism and heightened status-seeking materialism. Imitators from the working and middle classes found gratification in commodity culture and the reconstruction of their self via status products. Psychologists and consumer researchers began to view the consumer as an entity and argued that the total of the individual's thoughts, perceptions and feelings, with reference to himself, define the 'self concept' (Schlenker, 1975; Rosenberg, 1979; Sirgy, 1982), which can be employed as a flexible and extremely useful tool for further research and understanding of consumption processes. A proliferation of studies followed during the 1980s, with the self-concept to be broken down and analyzed in depth through its various dimensions such as the actual self, ideal self (Landon, 1974; Sirgy, 1985; Graeff, 1996; Graeff, 1997), public self (Gould and Barak, 1988; Fransen et al., 2008), social self-image (Bogart, 1986; Sirgy et al., 1997; O’Cass and Frost, 2002) and the over-discussed concept of the extended self (Belk, 1984; Belk, 1988; Cohen, 1989; Tian and Belk, 2005). Inherent to the notion of the 'self-concept' is the self-esteem motive referring to the tendency to engage with (often conspicuous) consumption experiences that enhance the individual's self (Sirgy, 1982). The increasing popularity of symbolic interactionist approaches, experiential consumption and semiotics from the beginning of the 1980s inspired the study of product symbolism, socialization theories of consumption and overall the interest in conspicuous consumption as a means of performance and social positioning (Csikszentmihalyi and Rochberg-Halton, 1981; Holbrook and Hirschman, 1982; Solomon, 1983; Appadurai, 1986; McCracken, 1986; Mick, 1986; Belk, 1988).

The lavish spending and group competition for status in the 1980s was followed by harder economic times and, as an outcome of consumption excessiveness, consumer debt doubled (Page, 1992). After decades of neo-liberal policies that promoted market solutions consumption becomes increasingly defined as a space in which individuals express their social awareness about the community and the environment (Prothero and Fitchett, 2000). Altruistic tendencies, globalization and acculturation processes, asset-based and servicedriven New Economies, New Age spiritual practices and a progressive era of benevolence and activism synthesized some aspects of the socio-economic jigsaw puzzle in the 1990s (Trigilia, 2002) and to some extent these processes continue today. The ostentatious consumption of the 1980s seemed to have reached its peak, although the explosion of counterfeit status goods in developed and developing countries demonstrate a growing global trend to consume for status, at least from an empirical perspective (Mason, 1998). We also 
note the thorough examination of how lifestyles and product symbolism shape the perceptions and preferences of 'postmodern' consumers (Featherstone, 1991; Hirschman and Holbrook, 1992) considerably diminished the significance of social class variables, like income and education, for marketing and consumer research. Only few studies (Kapferer, 1998; O' Cass and Frost, 2002; Belk, Ger and Askegaard, 2003; Amaldoss and Jain, 2005) have focused on the extravagant spending and uniqueness via consumption and as Chaudhuri and Manjumar (2006) suggest, direct display of wealth and outrageous flamboyance are no longer indicators of status, which is conveyed through in more subtle and sophisticated ways. Meanwhile, global consumer goods, in the form of brands, communicate collective cultural and status consumption identities to individuals interested in increasing their social standing (Holt, 2002). The popularity of prestige brands endorsed the predilection for consumptionfocused lifestyles and the price competition between luxury manufacturing industries rendered more accessible for middle classes the possession and display of commodities with conspicuous value (Vigneron and Johnson, 1999, Truong et al, 2008).

\section{Conclusions}

By embarking upon a close reading (or reminding) of Veblen's most famous work, this study examined the evolution of conspicuous consumption phenomena throughout the twentieth century. We observe that the initial reception of Veblen's book, as a critical observation upon the mannerisms of the upper-classes, encouraged his contemporary economists to marginalize the idea that the consumption preferences of the Rational Economic Man could also be driven by impulsive forces such as emulation and social comparison. The disastrous impact of the Great Depression on the income and financial capability of consumers in the United States and Europe, encouraged a growing number of social scientists to pay some attention on ostentatious activities and wasteful expenditure of goods and services. The economic recovery of the post-war period and the advent of the phenomenon of mass-consumption reshuffled social structures and revitalized the interest into conspicuous consumption practices. In this context economists introduced the generic terms 'Veblen', 'snob' and 'bandwagon effect.' From the 1950s until the 1980s, we observe that Veblen can be viewed as the intellectual ancestor in Galbraith's and Packard's critical accounts on consumer culture and Bourdieu's views on the aesthetic aspects of conspicuousness and consumption. Some of the first theorists of consumer behaviour fascinated by the new market conditions of affluence - reappraised both product symbolism 
and consumption for status. However the emerging models of consumer decision making, widely used for pedagogical purposes, did not escape from the legacy of utilitarian economic theories along with the behavioural principles of cognitive psychology and information processing models. General theories of rational consumer demand avoided acknowledging and discussing the irrationalities and absurdities in the behaviour of the conspicuous consumer. Finally, works on conspicuous consumption were revived in the post-war period of mass-consumption and affluence mainly by public commentators of consumer culture. These forms of extrovert display of wealth began to fall out fashion at the end of the twentieth century with well-educated consumers prepared pay more attention to ethical consumption and social differentiation achieved through taste and intellectual efforts.

\section{References}

Adorno, T. (1941), "Veblen's attack on culture", Studies in Philosophy and Social Science, Vol. 9 No. 3, pp. $389-413$.

Alcott, B. (2004), “John Rae and Thorstein Veblen”, Journal of Economic Issues, Vol. 38 No.3, pp. 765-786.

Amaldoss, W. and Jain, S. (2005), "Pricing of conspicuous goods: A competitive analysis of social effects", Journal of Marketing Research, Vol. 42 No. 1, pp. 30-32.

Appadurai, A. (1986), The social life of things: commodities in cultural perspective, Cambridge University Press, Cambridge.

Bartels, R. (1951), "Influences on the development of marketing thought, 1900-1923", Journal of Marketing, Vol. 51 No. 16, pp. 1-17.

Bartels, R. (1962), The Development of Marketing Thought, Irwin Press, Homewood.

Bartels, R. (1965), "Development of Marketing Thought”, in Schwartz, G. (Ed.), Science in Marketing, John Willey and Sons, New York.

Baudrillard, J. (1968/1996), The system of objects, Verso, New York.

Bayton, J. (1958), "Motivation, cognition, learning basic factors in consumer behaviour", Journal of Marketing, Vol. 22 No. 3, pp. 282-230.

Belk, R. (1984), "Cultural and historical differences in concepts of self and their effects on attitudes towards having and giving", Advances in Consumer Research, Vol. 11 No. 1, pp. 753-760.

Belk, R. (1986), "Yuppies as arbiters of the emerging consumption style", Advances in Consumer Research, Vol. 13 No. 1, pp. 514-519. 
Belk, R. (1988), "Possessions and the extended self", Journal of Consumer Research, Vol. 15 No. 2, pp. 139-168.

Belk, R. Ger, G. and Askeergard, S. (2003), "The fire of desire: a multisided inquiry into consumer passion”, Journal of Consumer Research, Vol. 30 No. 3, pp. 326-351.

Blum, J. M. (1976), V was for victory: politics and American culture during World War II, Harcourt Brace Jovanovich, London.

Bocock, R. (1993), Consumption, Routledge, London.

Bogart, L. (1986), "What forces shape the future of advertising research?", Journal of Advertising Research, Vol. 26 No 1, pp. 99-105.

Bourdieu, P. (1984), Distinction: a social critique of the judgment of taste, Routledge and Kegan Paul, London.

Campbell, C. (1987), The Romantic Ethic And The Spirit Of Modern Consumerism, Basil Blackwell, Oxford.

Carver, T. (1918), “The Behavioristic Man”, Quarterly Journal of Economics, Vol. 33 No. 4, pp. 195-201.

Chaudhuri, H. and Manjumar, M. (2006), "Of Diamonds and Desires: Understanding Conspicuous Consumption from a Contemporary Marketing Perspective", Academy of Marketing Science Review, Vol 11.

Cohen, J. (1989), “An over-extended self?”, Journal of Consumer Research, Vol. 16 No. 1, pp. $125-128$.

Coleman, R. (1961), “The Significance of Social Stratification in Selling”, in Bell, M. (Ed.) Marketing a Maturing Discipline: Proceedings of the American Marketing Association, December 28-30, American Marketing Association, Chicago, pp. 171 - 184.

Coleman, R. (1983), "The continuing significance of social class to marketing", Journal of Consumer Research, Vol. 10 No. 3, pp. 256-280.

Collins, R. (2000), More: the politics of economic growth in postwar America, Oxford University Press, Oxford.

Commons, R. (1934), Institutional Economics - Its Place in Political Economy, The Macmillan Company, New York.

Covert, T. A. (2003), "Consumption and citizenship during the Second World War: product advertising in women's magazines", Journal of Consumer Culture, Vol. 3 No. 3, pp. 315 342.

Csikszentmihalyi, M. and Rochberg - Halton, E. (1981), The meaning of things: domestic symbols and the self, Cambridge University Press, Cambridge. 
Cummings, J. (1899), "Review of the Theory of the Leisure Class", Journal of Political Economy, Vol. 12, pp. $425-455$.

Curtis, W. (1972), “Social class or income?”, Journal of Marketing, Vol. 36 No. 1, pp. 67-68.

Deaton, A. and Muellbauer, J. (1980), Economics and Consumer Behaviour, Cambridge University Press, Cambridge.

Dobriansky, L. (1957), Veblenism: a new critique, Public Affairs Press, Washington.

Dominquez, L. and Page, A. (1981), "Stratification in consumer behaviour research: a Reexamination", Journal of the Academy of Marketing Science, Vol. 9 No. 3, pp. 250-273.

Dorfman, J. (1934), Thorstein Veblen and his America, Viking Press, New York.

Dorfman, J. (1963), Institutional economics: Veblen, Commons, and Mitchell reconsidered: a series of lectures, University of California, Berkeley.

Duesenberry, S. J. (1949), Income, Saving and the Theory of Consumer Behaviour, Oxford University Press, New York.

Ebner, A. (2008), The institutions of the market: organizations, social system and governance, Oxford University Press, Oxford.

Edgell, S. and Tilman, R. (1991), "John Rae and Thorstein Veblen on conspicuous consumption: a neglected intellectual relationship", History of Political Economy, Vol. 23 No. 4, pp. 731-744.

Engel, J. Kollat, D. and Blackwell, R. (1968), Consumer behaviour, Holt, New York.

Featherstone, M. (1991), Consumer culture and postmodernism, Sage publications, London.

Foxall, G. (1999), “The contextual stance”, Philosophical Psychology, Vol. 12, pp. 25-46.

Fransen, M., et al. (2008), "Rest in peace? Brand induced mortality salience and consumer behaviour", Journal of Business Research, Vol. 61 No. 10, pp. 1053-1061.

Friedman, M. (1957), A theory of the consumption function, Princeton University Press, Princeton.

Friedman, W. (2004), The birth of the salesman: the transformation of selling in America, Harvard University Press, Cambridge Mass.

Fromm, E. (1947), Man for Himself, Routledge and Kegan Paul, London.

Galbraith, J. (1957/1987), The affluent society, 4rth ed., Pelican Books, London.

Galbraith, J. (1971), The New Industrial State, $2^{\text {nd }}$ ed. Houghton Mifflin, Boston. 
Galbraith, K. (1987), A history of economics: the past as the present, Penguin books, New York.

Goodwin, N. Ackerman, F. and Kiron, D. (1996), The consumer society: Frontier Issues in Economic Thought, Island Press, New York.

Gould, S. and Barak, B. (1988), "Public self-consciousness and consumption behaviour", Journal of Social Psychology, Vol. 128 No. 3, pp. 393-401.

Graeff, T. (1996), "Image congruence effects on product evaluations: the role of selfmonitoring and public/private consumption", Psychology and Marketing, Vol. 13 No. 5, pp. 489-499.

Graeff, T. (1997), "Consumption situations and the effects of brand image on consumers' brand evaluations", Psychology and Marketing, Vol. 14 No. 1, pp. 49-70.

Green, P. (1977), “A new approach to market segmentation”, Business Horizons, Vol. 20 No. 1, pp. 61-74.

Gregory, C.A. (1982), Gifts and Commodities, London, Academic Press.

Jones, B. and Monieson, D. (1990), "Early Development of the Philosophy of Marketing", Journal of Marketing, Vol. 54 No. 1, pp. 102-113.

Hirschman, E. and Holbrook, M. (1992), Postmodern consumer research: the study of consumption as text, Sage, London.

Hodgson, G. (1988), Economics and Institutions: a manifesto for modern institutional economics, Polity Press, Cambridge.

Hodgson, G. (2006), “What are Institutions?”, Journal of Economic Issues, Vol. 40 No. 1, pp. $1-27$.

Holbrook, M. and Hirschman, E. (1982), "The experiential aspects of consumer behaviour: consumer fantasies, feelings and fun”, Journal of Consumer Research, Vol. 9 No. 2, pp. 132141.

Holbrook, M. (1987), "What is Consumer Research?”, Journal of Consumer Research, Vol. 14 No. 1, pp. 128-132.

Holbrook, M. and O' Shaughnessy, J. (1988), “On the scientific status of consumer research and the need for an interpretive approach of studying consumption behavior", Journal of Consumer Research, Vol. 15 No. 3, pp. 398-402.

Holt, D. (2002), "Why do brands cause trouble? A dialectic theory of consumer culture and branding", Journal of Consumer Research, Vol. 29 No. 1, pp. 70 - 90.

Hood, J. (2005), Selling the dream: why advertising is good business, Praeger, London. 
Horowitz, D. (1994), Vance Packard and American Social Criticism, University of North Carolina Press, Chapel Hill.

Howard, J. and Sheth, J. (1969), The theory of buyer behaviour, John Willey and sons: New York.

Hunt, A. (1996), Governance of the consuming passions: a history of sumptuary law, St Martins, New York.

Kahl, J. (1957), The American class structure, Rinehart, New York.

Kapferer, J. (1998), "Why are we seduced by luxury brands?", Journal of Brand Management, Vol. 6 No. 1, pp. 44-53.

Katona, G. (1951), Psychological Analysis of Economic Behaviour, McGraw Hill, New York.

Katona, G. (1953), "Rational Behavior and Economic Behavior", Psychological Review, Vol. 60 No. 5, pp. 307-318.

Katz, E. and Lazarsfeld, P. (1955), Personal influence: the part played by people in the flow of mass communications, Free Press, Glencoe Ill.

Keynes, J. M. (1936), The General Theory of Employment, Interest and Money, McMillan, London.

Knight, F. (1925), "Fact and Metaphysics in Economic Psychology", American Economic Review, Vol. 15 No. 4, pp. $247-266$.

Kotler, P. (1965), "Behavioural models for analyzing buyers”, Journal of Marketing, Vol. 29 No. 4, pp. 37-45.

Kotler, P. and Levy, S. (1969), "Broadening the concept of marketing", Journal of Marketing, Vol. 33 No.1, pp. 10-15.

Landon, L. (1974), "Self-concept, ideal self concept, and consumer purchase intentions", Journal of Consumer Research, Vol. 1 No. 2, pp. 44-51.

Landsman, M. (2005) Dictatorship and Demand: The Politics of Consumerism in West Germany, Harvard University Press: Cambridge, MA

Lannoy, R. (1971), The speaking tree: a study of Indian culture and society, Oxford University Press, London.

Lears, T.J.J. (1989), Beyond Veblen in Bronner, S. (Ed.), Consuming Visions: Accumulation and Display of Goods in America, 1880 - 1920.: Norton, New York, pp. 73-97.

Leavitt, J. (1954), "A note on some experimental findings about the meaning of price", Journal of Business, Vol. 27 No. 4, pp 205-210. 
Leibenstein, H. (1950), "Bandwagon, Snob and Veblen Effects in the Theory of Consumer Demand", Quarterly Journal of Economics, Vol. 64 No. 2, pp. 183-207.

Leong, S. (1989), "A citation analysis of the Journal of Consumer Research", Journal of Consumer Research, Vol. 15 No. 4, pp. 492-497.

Levy, S. (1959), “Symbols for sale”, Harvard Business Review, Vol. 37 No. 4, pp. 117-124.

Malinowski, B. (1922), Argonauts of the Western Pacific: An Account of Native Enterprise and Adventure in the Archipelagoes of Melanesian New Guinea, George Routledge \& Sons, Ltd.

Marcuse, H. (1968), One dimensional man, Sphere Books, London.

Marshall, A. (1895), Principles of Economics, 3rd ed. Macmillan, London.

Martineau, P. (1958), "Social classes and spending behaviour", Journal of Marketing, Vol 23 No. 2, pp. 121-131.

Marx, K. (1883/1981), Capital: a critique of political economy, Penguin. Books in association with New Left Review, Harmondsworth.

Mason, R. (1981), Conspicuous Consumption: A Study of Exceptional Consumer Behaviour, St. Martin's Press, New York.

Mason, R. (1995), "Interpersonal effects on consumer demand in economic theory and marketing thought, 1890 - 1950", Journal of Economic Issues, Vol. 29 No. 3, pp. 871-882.

Mason, R. (1998), The Economics of Conspicuous Consumption: Theory and Thought since 1700, Edward Elgar, Aldershot.

Mauss, M. (1922/1990), The Gift: forms and functions of exchange in archaic societies, London: Routledge.

McCann, C. (1957), Women and Department Store Advertising, Social Research, Chicago.

McCracken, G. (1986), "Culture and consumption: a theoretical account of the structure and movement of the cultural meaning of consumer goods", Journal of Consumer Research, Vol. 13 No. 1, pp. 71-84.

McMurry, R. (1944), "Psychology in selling”, Journal of Marketing, Vol. 9 No. 2, pp. 114115 .

Mestrovic, S. (2003), The barbarian temperament: toward postmodern critical theory, Routledge, London.

Mick, D. (1986), "Consumer research and semiotics: exploring the morphology of sings, symbols, and significance”, Journal of Consumer Research, Vol. 13 No. 2, pp. 196-213 
Morgan, L. (1877), Ancient Society, Harvard University Press, Cambridge Mass.

Mouhammed, A. (1999), "Visions and revisions of Neo-Classical economics: Veblenian Perspectives", International Journal of Politics, Culture and Society, Vol. 13 No. 2, pp. 169 186.

Myers, J. and Mount, J. (1973), "More on social class vs. income as correlates of buying behaviour", Journal of Marketing, Vol. 37 No. 2, pp. 71-73.

Nam, C. (1963), Methodology and Scores of Socioeconomic Status, US Bureau of the Census, Washington.

Nicosia, F. (1966), Consumer decision processes: marketing and advertising implications, Englewood Cliffs: New Jersey.

Newman, J. (1957), Motivation Research and Marketing Management, Harvard University, Cambridge.

O'Cass, A. and Frost, E. (2002), "Status brands: examining the effects of non-product related brand associations on status and conspicuous consumption", Journal of Product and Brand Management, Vol. 11 No. 2, pp. 67-89.

Packard, V. (1957), The Hidden Persuaders, McKay, New York.

Packard, V. (1959), The status seekers: an exploration of class behavior in America, McKay, New York.

Page, C. (1992), A History of Conspicuous Consumption. in Rudmin, F. and Richins, M. (Ed) 1992. Meaning, Measure, and Morality of Materialism, Association for Consumer Research, Provo, UT, pp. 82-87.

Patsiaouras, G. and Fitchett, A. J. (2009), "Veblen and Darwin: tracing the evolutionary roots of consumer research", Journal of Marketing Management, Vol. 25 No. 7/8, pp. 729-744.

Prothero, A. and Fitchett, J. (2000), "Greening Capitalism: Opportunities for a Green Commodity”, Journal of Macromarketing, Vol. 20 No. 1, pp. 46-56.

Rae, J. (1834/1964), Statement of Some New Principles on the Subject of Political Economy: Exposing the Fallacies of the System of Free Trade, and of Some Other Doctrines Maintained in the "Wealth of Nations." 1834. Reprint, Augustus M. Kelley, New York: 1964.

Riesman, D. (1953), Thorstein Veblen: a critical interpretation, Schribners, New York.

Riesman, D. (1961), The lonely crowd: a study of the changing American character, Yale University Press, New Haven, Conn.

Ritzer, G. (2001), Explorations in the sociology of consumption: fast food, credit cards and casinos, Sage, London.

Rosenberg, M. (1979), Conceiving the self, Basic books, New York. 
Savitt, R. (1980), “Historical Research in Marketing”, Journal of Marketing, Vol. 44 No. 4, pp 52-58.

Schaninger, C. (1981), "Social class versus income revisited: an empirical investigation", Journal of Marketing Research, Vol. 4, pp. 192-208.

Shankar, A. and Fitchett, J. (2002), "Having, Being and Consumption”, Journal of Marketing Management, Vol. 18 No. 5(6), pp. 501-516.

Schlenker, B. (1975), "Self-presentation: Managing the impression of consistency when reality interferes with self-enhancement", Journal of Personality and Social Psychology, Vol. 32 No. 6, pp. 1030-1037.

Simich, L. and Tilman, R. (1980), "Critical theory and institutional economics", Journal of Economic Issues, Vol. 14 No. 3, pp. 631- 649.

Sirgy, J. (1982), "Self-concept in consumer behaviour: A Critical Review", Journal of Consumer Research, Vol. 9 No. 3, pp. 287-300.

Sirgy, J. (1985), "Using self-congruity and ideal congruity to predict purchase motivation", Journal of Business Research, Vol. 13 No. 3, pp. 195-206.

Sirgy, et al. (1997), "Assessing the predictive validity of two methods of measuring selfimage congruence", Journal of the American Academy of Science, Vol. 25 No. 3, pp. 229242.

Smith, A. (1776/1999), The wealth of nations, Penguin, London.

Smith, W. (1956), "Product differentiation and market segmentation as alternative marketing strategies", Journal of Marketing, Vol. 21 No. 1, pp. 3-8.

Solomon, M. (1983), "The role of products as social stimuli: a symbolic interactionism perspective", Journal of Consumer Research, Vol. 10 No. 3, pp. 319-330.

Solomon, M. (1992), Consumer Behavior: Buying, Having and Being, Allyn and Bacon, Boston.

Slater, D. (1997), Consumer, culture and modernity, Polity Press, Oxford.

Stabile, D. (1982), "Thorstein Veblen and his socialist contemporaries: a critical comparison", Journal of Economic Issues, Vol. 16 No. 1, pp. 1 - 28.

Stern, B. (2004), "The importance of being Ernest: commemorating Dichter's contribution to Advertising Research", Journal of Advertising Research, Vol. 44 No. 2, pp. 165-169.

Schmid, A. (2004), Conflict and cooperation: institutional and behavioral economics, Malden Mass; Blackwell, Oxford.

Tadajewski, M. (2006), "Remembering motivation research: toward an alternative genealogy of interpretive consumer research", Marketing Theory, Vol. 6 No. 4, pp. 429-466. 
Tian, K. and Belk, R. (2005), "Extended self and possessions in the workplace", Journal of Consumer Research, Vol 32 No. 2, pp. 297-310.

Tilman, R. (1992), Thorstein Veblen and his critics, 1891-1963: conservative, liberal and radical perspectives, Princeton University Press, Princeton, N.J.

Tilman, R (2007), Thorstein Veblen and the Enrichment of Evolutionary Naturalism, University of Missouri Press, Columbia, MO.

Trigg, A. (2001), "Veblen, Bourdieu and conspicuous consumption", Journal of Economic Issues, Vol. 35 No. 1, pp. 99-115.

Trigilia, C. (2002), Economic sociology: state, market and society in modern capitalism, Blackwell, Oxford.

Truong, Y. Simmons, G. McColl, R. and Kitchen, P. (2008), "Status and conspicuousness are they related? Strategic marketing implications for luxury brands", Journal of Strategic Marketing, Vol. 16 No. 3, pp. 189-203.

Twain, M. (1968), The gilded age: a tale of today, University of Washington Press, Washington.

Wann, T. (1964), Behaviorism and phenomenology: contrasting bases for modern psychology, University of Chicago Press, Chicago.

Warner, W. L. Meeker, M. and Eels, K. (1949), Social class in America: a manual of procedure for the measurement of social status, Science Research Associates, Chicago.

Watson, J. (1970), Behaviorism, Norton Library, New York.

Webb, D. and Shawver, D. (1989), A critical examination of the influence of institutional economics on the development of early marketing thought. in Nevett, T. Whitney, K. and Hollander, S. (Ed) Marketing History: The Emerging Discipline : Proceedings from the Fourth Conference on Historical Research in Marketing and Marketing Thought, East Lansing: Michigan State University, pp. 22-39.

Ritzer, G. (2001), Explorations in the sociology of consumption: fast food, credit cards and casinos, Sage, London.

Weber, M. (1930), The Protestant ethic and the spirit of capitalism, Unwin University Books, London.

Wieser, F. (1914), Social Economics, George Allen and Unwin, London.

Wind, Y. (1978), "Issues and advances in segmentation research", Journal of Marketing Research, Vol. 15 No. 3, pp. 317-337.

Woods, W. (1960), "Psychological dimensions of consumer decision", Journal of Marketing, Vol. 24 No. 3, pp. 15-20. 
Veblen, T. (1899), The Theory of the Leisure Class: an economic study of institutions, Random House, New York.

Vigneron, F. and Johnson, L. (1999), "A review and a conceptual framework for prestigeseeking behaviour", Academy of Marketing Science Review, Vol 1.

Viner, J. (1925), “The Utility Concept in Value Theory and its Critics", Journal of Political Economy, Vol. 33 No. 1, pp. $369-387$.

Vinning, R. (1939), "Suggestions of Keynes in the writings of Veblen", Journal of Political Economy, Vol. 47 No. 5, pp. 692 - 704.

Yamey, B. (1964), Capital, saving and credit in peasant societies: studies from Asia, Oceania, the Caribbean and Middle America, Allen \& Unwin, London. 